\title{
RENEWABLE ENERGY FEDERALISM IN RUSSIA: REGIONS AS NEW ACTORS FOR THE PROMOTION OF CLEAN ENERGY
}

\author{
Anatole Boute
}

Published in Journal of Environmental Law (2013), published online May 30, 2013 at: http://jel.oxfordjournals.org/content/early/2013/05/30/jel.eqt005.abstract

\begin{abstract}
Russia is not only rich in natural gas, oil, coal and uranium. It also holds a considerable renewable energy resource base. The Federal Electricity Law mandates the federal Government to stimulate the development of renewable energy sources. However, so far, the Government has failed to create a functioning regulatory framework that would ensure the financial viability of these investments. This article examines the role that regional authorities could play in developing clean energy in the Russian Federation. Building further upon the environmental federalism literature, this article analyses the regulatory barriers to regional feed-in tariffs in Russia and, based on the US experience, proposes legal solutions to overcome these barriers. Russia - because of its role as a fossil fuel superpower, its weak track record on climate change mitigation, together with high political centralisation of power - is a unique case for an analysis of the role of regions as innovators of sustainable development.
\end{abstract}

Keywords: Renewable energy, feed-in tariffs, environmental federalism, Russia

\section{Introduction}

The Russian Federation holds a considerable renewable energy resource base. ${ }^{1}$ However, developing this potential is a controversial issue for domestic policymakers, especially because of a tradition of comparatively low energy prices, Russia's position as fossil fuel superpower and its careful approach to climate change mitigation. ${ }^{2}$ Since

\footnotetext{
* Lecturer, University of Aberdeen, School of Law (a.boute@abdn.ac.uk) and Legal Adviser, IFC Russia Renewable Energy Program (The World Bank Group). This article has benefited from considerable input in the context of the author's involvement as legal adviser to the IFC Russia Renewable Energy Program. It is based on a presentation to the research seminar on New Actors in the Russian Energy Sector organised by the Russian and Caspian Energy Developments and Aleksanteri CoE groups in Oslo on 12-13 December 2012. The author is grateful to Margarita Balmaceda and Arild Moe for the invitation to participate in the workshop. Many thanks to Katharina Merkel and Neale Tosh for outstanding research assistance and to Arild Moe, Veli-Pekka Tynkkynen, Patrick Willems, Anna Vishniakova and Alexey Zhikharev for their comments on an earlier draft of this article. This article represents the views of the author only, not necessarily of the organizations to which the author is associated.

${ }^{1}$ International Energy Agency (IEA), World Energy Outlook (IEA 2011) 325-327; International Finance Corporation (IFC), Renewable Energy Policy in Russia: Waking the Green Giant (IFC 2011) 7 ,

<http://www1.ifc.org/wps/wcm/connect/region_ext_content/regions/europe+middle+east+and+north+ africa/ifc+in+europe+and+central+asia/publications/renewable+energy+policy+in+russia+-

+waking+the+green+giant> accessed 3 January 2013.

${ }^{2}$ IFC, Renewable Energy Policy in Russia (n 1) 4.
} 
November 2007, the Federal Electricity Law No. 35-FZ 3 mandates the Government of the Russian Federation to promote the development of renewable energy sources. In 2009 , the Government adopted a national renewable energy target of 4.5 per cent of electricity consumption in 2020. ${ }^{4}$ However, the Government has so far failed to create a regulatory framework that would ensure the financial viability of renewable energy investments. In the absence of a functioning renewable energy support scheme, Russia runs the risk of missing the boat of the Green Revolution and lagging significantly behind developed countries and other BRIC economies ${ }^{5}$ in the field of the clean technology industry.

This article analyses the role that regional authorities could play in developing Russia's renewable energy potential. Faced with regulatory paralysis at federal government level, regions of the Russian Federation have started to implement their own renewable energy policies. The promotion of renewable energy sources could be a way for regions to stimulate local employment, innovation and secure electricity supply, particularly for regions that are dependent on energy imports. ${ }^{6}$ Electricity production from renewable energy sources could also be a way for regions to address the increasing environmental and economic challenges posed by waste from the forestry, agriculture and animal industries. ${ }^{7}$ To ensure the financial viability of renewable energy investments (and in order to level the playing field with traditional modes of electricity production), some regional authorities have sought to establish regulated prices for the electricity produced from renewable energy sources (RES-E). ${ }^{8}$

\footnotetext{
${ }^{3}$ Federal'nyi Zakon 'Ob elektroenergetike', with subsequent amendments, No. 35-FZ, signed 26 March 2003, Sobranie Zakonodatel'stva Rossiiskoi Federatsii (SZ RF) (31 March 2003) No. 13 item 1177 (hereinafter the 'Federal Electricity Law').

${ }^{4}$ Excluding hydropower installations with an installed capacity above $25 \mathrm{MW}$. Rasporiazhenie Pravitel'stva RF 'Osnovnye napravleniia gosudarstvennoi politiki v sfere povysheniia energeticheskoi effektivnosti elektroenergetiki osnove ispol'zovaniia vozobnovliaemykh istochnikov energii na period do 2020 goda', No. 1-r, signed 8 January 2009, Sobranie Zakonodatel'stva Rossiiskoi Federatsii (SZ RF) (26 January 2009) No. 4 item 515 (hereinafter 'Government Resolution No. 1-r on Energy Efficiency Improvements in the Electricity Sector Based on the Use of Renewable Energy Sources').

${ }^{5}$ For a global overview of support schemes for renewable energy, see Renewable Energy Policy Network for the 21st Century ('REN21'), Global Status Report <www.ren21.net> accessed 3 January 2013.

${ }^{6}$ Climate Change Global Services ('CCGS'), Razvitie Vozobnovliaemykh Istochnikov Energii $v$ Kaluzhskoi Oblasti (Report for the IFC Russia Renewable Energy Programme, 2012) 38-39.

${ }^{7}$ ibid.

${ }^{8}$ See e.g. Rasporiazhenie Pravitel'stva Belgorodskoi oblasti 'Ob utverzhdenii vremennykh pravil rascheta ekonomicheski obosnovannogo reguliruemogo eko-tarifa na elektricheskuiu energiiu (moshhnost'), proizvedennuiu na ob'ektakh elektroenergetiki, ispol'zuiushchikh vozobnovliaemye istochniki energii', No. 233-pp, signed 6 July 2009 (hereinafter the 'Resolution of the Government of the Belgorod Oblast' on the Approval of Eco-tariffs in the Electricity Sector'); Prikaz priniat Komissiei po gosudarstvennomu regulirovaniiu tsen i tarifov v Belgorodskoi oblasti 'Ob ustanovlenii tarifov na elektricheskuiu energiiu (moshchnost'), proizvodimuiu kvalifitsirovannoi biogazovoi elektrostantsiei OOO “Al'tEnergo" na 2013 g.', No. 24/1, signed 10 December 2012 (hereinafter 'Order of the Belgorod Tariff Authority Adopting the Tariff for the Electricity Produced from Biogas by Al'tEnergo'); Prikaz REK Vologodskoi oblasti 'Ob ustanovlenii tarifa na elektricheskuiu energiiu (moshchnost'), proizvedennuiu na funktsioniruiushchem na osnove ispol'zovaniia vozobnovliaemykh istochnikov energii kvalifitsirovannom generiruiushchem ob'ekte OAO PMTETS 'Belyi Ruchei' i priobretaemuiu v tseliakh kompensatsii poter' v elektricheskikh setiakh', No. 490, signed 22 October 2012 (hereinafter 'Order of the Vologda Tariff Authority Adopting the Tariff for the Electricity Produced from Renewable Energy Sources by the Belyi Ruchei Installation'); Postanovlenie gosudarstvennogo komiteta Respubliki Kareliia po tsenam i tarifam 'O gosudarstvennom regulirovanii tarifov na elektricheskuiu energiu, proizvodimuiu maloi gidroelektrostantsiei 'Liaskelia' zakrytogo aktsionernogo obshchestva 'Nord Gidro", No. 258, signed 12 December 2012 (hereinafter 'Order of
} 
However, regional RES-E tariffs in Russia face important regulatory and political obstacles from the federal government. ${ }^{9}$ In particular, federal authorities exercise control over electricity tariffs and the qualification (i.e. certification) of renewable energy installations. The objective of this paper is to analyse the regulatory and political barriers to regional renewable energy tariffs in Russia and to propose ways to overcome these barriers so as to enable the development of regional renewable energy policies in the absence of federal support.

The structure of the argument proceeds as follows. The second section of this paper starts with a conceptual analysis of the legitimacy of regional renewable energy policies in Russia - an issue of particular importance given the centralised nature of the regulation of Russia's electricity sector. Based on the general 'environmental federalism' literature, which examines the division of powers in the field of environmental protection, this section aims to assess the effectiveness of a regional as opposed to a federal approach to the support of renewable energy. This analysis aims to explain the current lack of support for an ambitious federal renewable energy policy in Russia. It proposes possible reasons that might explain higher regional interest in renewable energy. From a law and economics perspective, this analysis is necessary to appreciate the importance of guaranteeing to regional authorities sufficient scope to implement renewable energy policies within federal regulatory boundaries.

Section three of this paper analyses the division of powers in respect of the support of RES-E in Russia by looking at the Russian Constitution and the Federal Electricity Law. The paper also looks at the regulation of renewable energy under the Federal Energy Efficiency Law No. 261-FZ of 23 November $2009 .{ }^{10}$ The objective of this analysis is to understand the legal framework governing regional RES-E tariffs in Russia: is there a legal basis for regional RES-E tariff initiatives? The focus is on regional powers to guarantee the purchase of RES-E at regulated prices for a longterm period. ${ }^{11}$ Regional subsidies are excluded from this analysis. ${ }^{12}$

the Karelian Tariff Authority Adopting the Tariff for the Electricity Produced by the Small Hydropower Plant Liaskelia'); Postanovlenie Komiteta gosudarstvennogo tsen i tarifov chukotskogo avtonomnogo okruga 'Ob ustanovlenii tarifa na elektricheskuyu energiyu (moshchnost'), proizvodimuyu vetrovymi elektrostantsiiami, s ispol'zovaniem kotorykh osushchestvliaetsia proizvodstvo i postavka elektricheskoi energii (moshchnosti) na roznichnom rynke chukotskogo avtonomnogo okruga', No. 6-e/Z, signed 15 June 2011 (hereinafter the 'Decree of the Energy Tariff Commission of the Chukotka Autonomous Administration Adopting a Tariff for the Electricity Produced from Wind Turbines').

${ }^{9}$ For an analysis of these barriers, see Tsentr Infrastrukturnykh Issledovanii, Itogovyi Otchet Konsul'tanta po Proektu 'Analiz Zakonodatel'stva o Vozobnovliaemykh Istochnikakh Energii $v$ Kaluzhskoi Oblasti' (Report for the IFC Russia Renewable Energy Programme, 2012).

${ }^{10}$ Federal'nyi Zakon 'Ob energosberezhenii i o povyshenii energeticheskoi effektivnosti' with subsequent amendments, No. 261-FZ, signed 23 November 2009, Sobranie Zakonodatel'stva Rossiiskoi Federatsii (SZ RF) (30 November 2009) No. 48 item 5711 (hereinafter the 'Federal Energy Efficiency Law').

${ }^{11}$ This article does not discuss the isolated and regulated (non-price) zones of the Russian electricity system. On the regulation of the Russian electricity market, see Anatole Boute, 'The Russian Electricity Market Reform: Towards the Re-regulation of the Liberalised Market?' in Fereidoon Sioshansi (ed.), Evolution of Global Electricity Markets: New Paradigms, New Challenges, New Approaches (Elsevier, 2013, forthcoming).

${ }^{12}$ See Postanovlenie Pravitel'stva RF 'Ob utverzhdenii Pravil predostavleniia subsidii iz federal'nogo biudzheta biudzhetam sub' 'ektov RF na realizatsiiu regional'nykh programm $v$ oblasti 
Section four examines the regulatory barriers that could affect regional RES-E tariffs, in particular federal control over tariff setting in the electricity sector and federal qualification of renewable energy installations. Section five makes recommendations to overcome these obstacles. These recommendations are developed on the basis of a comparative law analysis with the US. This paper aims to build on the regulatory constructions that states in the US have developed to overcome federal obstacles to RES-E tariffs. Comparison with the US is relevant as it has a relatively similar constitutional division of powers to Russia and, more importantly, US states face comparable federal challenges to their RES-E tariff initiatives. Although inspired by the US, the recommendations put forward in this paper take into consideration the fact that Russia, in contrast to the US, still needs to complete its "first-generation" reforms, e.g. strengthen the rule of law, ensure the independency of its judicial system, guarantee the enforcement of contractual rights, limit corruption. ${ }^{13}$ In order to avoid the trap of an unsuccessful 'legal transplant', ${ }^{14}$ the recommendations of this paper are anchored in the very specific regulatory regime governing the Russian energy sector. More specifically, this paper looks at how regions in Russia could replicate the US approach based on their broader powers under the Russia's Federal Energy Efficiency Law.

An analysis of the role of regions for the promotion of clean energy in Russia is not only relevant to develop new mechanisms to unlock Russia's huge renewable energy potential in the absence of federal support. A study of Russia also makes a valuable contribution to the environmental federalism debate in general. Indeed, Russia because of its role as a fossil fuel superpower, its weak track record on climate change mitigation, together with its high political centralisation of power - is a unique case for an analysis of the role of regions as innovators of sustainable development.

\section{The Concept of Renewable Energy Federalism and its Application to Russia}

The determination of the appropriate level of government to promote renewable energy sources in federal states has been the subject of an intense debate in the political economy and law and economics literature, in particular in the United States ${ }^{15}$ but also in Canada ${ }^{16}$ and Australia. ${ }^{17}$ Similarly, in the European Union, a

energosberezheniia i povysheniia energeticheskoi effektivnosti, No. 746, signed 5 September 2011 Sobranie Zakonodatel'stva Rossiiskoi Federatsii (SZ RF) (12 September 2011) No. 37 item 5258 (hereinafter the 'Government Decree on Regional Energy Efficiency Subsidies). See also Tsentr Infrastrukturnykh Issledovanii (n 9) $59 \mathrm{ff}$.

${ }^{13}$ Rudiger Ahrend and William Tompson, 'Fifteen Years of Economic Reform in Russia: What has been Achieved? What Remains to be Done?', Organization for Economic Cooperation and Development Economics Department Working Paper No.430 (2005),

<http://EconPapers.repec.org/RePEc:oec:ecoaaa:430-en> accessed 3 January 2013.

${ }^{14}$ See e.g. David Nelken, 'The Meaning of Success in Transnational Legal Transfers' (2001) 19 Windsor Yearbook of Access to Justice 349.

${ }^{15}$ See e.g. Kirsten Engel, 'Why Not a Regional Approach to State Renewable Power Mandates?' (2011-2012) 3 San Diego J of Climate \& Energy L 79; Benjamin Sovacool, 'The Best of Both Worlds: Environmental Federalism and the Need for Federal Action on Renewable Energy and Climate Change' (2008) 27 Stanford Environmental LJ 397; Jim Rossi, 'The Shaky Political Economy Foundation of a National Renewable Electricity Requirement' (2011) U Ill L Rev 361.

${ }^{16}$ See e.g. See e.g. Scott Victor Valentine, 'Canada's Constitutional Separation of (Wind) Power' (2010) 38 Energy Policy 1918. 
lively debate centred around the harmonisation of national renewable energy support schemes: is it more efficient to support renewable energy sources in a decentralised way at the level of the individual member states or will a common EU approach generate efficiency gains? ${ }^{18}$ Based on the environmental federalism literature, scholars generally agree that the following criteria need to be taken into account to evaluate the efficiency of a regional (decentralised) versus a federal (centralised) approach to the promotion of renewable energy: (1) the geographical scope of the policy objectives pursued (i.e. global climate change mitigation or local environmental protection); (2) the diverging renewable energy resource base; (3) the role of regional authorities as innovators; and (4) incentives for a 'race to the top' between regions.

\subsection{Efficiency in Addressing Global v. Local Environmental Protection}

In accordance with the political economy and law and economics literature on environmental federalism, the appropriate level of government to address environmental problems depends on 'the geographic scope of the externalities in question'. ${ }^{19}$ One of the key objectives of renewable energy policies is to contribute to climate change mitigation. Given the global nature of climate change, a centralised approach appears to 'better match the geographic scope of the problem at hand than do state or local approaches. ${ }^{20}$

In Russia, climate change is far from a priority on the political agenda. ${ }^{21}$ While Russia has ratified the Kyoto Protocol ${ }^{22}$ and become the largest issuer of Emission Reduction Units under the Joint Implementation mechanism, Russia has so far refused to adhere to the second commitment period of the Protocol. ${ }^{23}$ Russia has adopted a Climate

\footnotetext{
${ }^{17}$ See e.g. Stephen Jones, 'The Future of Renewable Energy in Australia: A Test for Cooperative Federalism' (2009) 68 The Australian J of Public Administration 1.

${ }^{18}$ See e.g. Commission, 'The Support of Electricity from Renewable Energy Sources - Accompanying Document to the Proposal for a Directive on the Promotion of the Use of Energy from Renewable Sources' (Commission Staff Working Document) SEC (2008) 57, 15; Commission, 'The Support of Electricity from Renewable Energy Sources' (Communication) COM (2005) 627 final, 16-17; Council of European Energy Regulators, Implications of Non-harmonised Renewable Support Schemes - A CEER Conclusions Paper (2012), <www.energyregulators.eu/portal/page/portal/EER_HOME/EER_CONSULT/CLOSED\%20PUBLIC\%20CONSULT ATIONS/ELECTRICITY/Non\%20harmonised\%20RES> accessed 3 January 2013.

${ }^{19}$ David Spence, 'Federalism, Regulatory Lags, and the Political Economy of Energy Production' (2012) University of Texas School of Law - Law and Economics Research Paper No. 222, 21 <http://papers.ssrn.com/sol3/papers.cfm?abstract_id=2017280> accessed 3 January 2013.

${ }^{20}$ For an overview and criticism of the arguments underlying this claim, see Rossi, (n 15) 361. See also Engel, 'Why Not a Regional Approach to State Renewable Power Mandates?' (n 15) 83; Jared Snyder and Jonathan Binder, 'The Changing Climate of Cooperative Federalism: The Dynamic Role of the States in a National Strategy to Combat Climate Change' (2009) 27 UCLA J Envtl L \& Pol'y 231, 234.

${ }^{21}$ Anna Korppoo and Adnan Vatansever, A Climate Vision for Russia: From Rhetoric to Action, (Carnegie Endowment for International Peace, 2012) <http://carnegieendowment.org/files/RussiaClimate.pdf> accessed 3 January 2013.

${ }^{22}$ Federal'nyi Zakon 'O ratifikatsii Kiotskogo protokola k Ramochnoi konventsii Organizatsii Ob'edinennykh Natsii ob izmenenii klimata' with subsequent amendments, No. 128-FZ, signed 4 November 2004, Sobranie Zakonodatel'stva Rossiiskoi Federatsii (SZ RF) (08 November 2004) No. 45 item 4378 (hereinafter the 'Federal Law on the Ratification of the Kyoto Protocol to the United Nations Framework Convention for Climate Change').

${ }^{23}$ Report of the Conference of the Parties serving as the meeting of the Parties to the Kyoto Protocol on its seventh session, held in Durban from 28 November to 11 December 2011, Decision 1/CMP.7, Outcome of the work of the Ad Hoc Working Group on Further Commitments for Annex I Parties
} 
Doctrine, and has announced that it aims to reduce emissions by 25 per cent (as compared with 1990 levels) by $2020 .{ }^{24}$ Renewable energy sources are part of that Russian climate strategy. In practice, however, the contribution of renewable energy to the decarbonisation of energy supply is unlikely to be a sufficient reason to justify action in this field. The contribution of renewable energy to global environmental protection and the effectiveness of a federal approach to achieve this objective is thus not the most relevant criterion to assess renewable energy federalism in Russia.

The economic and local environmental benefits of renewable energy are more important elements for the development of renewable energy in Russia. Different regions of the Russian Federation (e.g. Belgorod, Archangelsk, Kaluga) ${ }^{25}$ face considerable challenges with respect to the management of waste, in particular from forestry, agriculture and the animal industry. Renewable energy policies can be a way for these regions to address this waste problem. ${ }^{26}$ Simultaneously, this policy could stimulate local employment (e.g. maintenance and operation of the generating facilities), ${ }^{27}$ innovation and new industrial developments. ${ }^{28}$ It could also favourably influence the security of energy supply in regional electricity systems, by modernising the energy infrastructure and improving the availability of energy sources for electricity production. ${ }^{29}$ This is an issue of particular importance in Russia for regions that are dependent on energy imports. ${ }^{30}$ In addition, these policies could stimulate the development of a regional renewable energy industry that could open new export opportunities. These local economic and environmental benefits are key reasons for states to support the use of renewable energy in regional energy systems. ${ }^{31}$

However, it is important to note that, in Russia, the centralisation of power and limited exposure of regional leaders to electoral pressure reduce the relevance of

\footnotetext{
under the Kyoto Protocol at its sixteenth session,

<http://unfecc.int/resource/docs/2011/cmp7/eng/10a01.pdf> accessed 3 January 2013.

${ }^{24}$ See Rasporiazhenie Prezidenta RF 'O Klimaticheskoi doktrine Rossiiskoi Federatsii' No. 861-r, signed 17 December 2009, Sobranie Zakonodatel'stva Rossiiskoi Federatsii (SZ RF) (21 December 2009) No. 51 item 6305 (the 'Resolution on the Climate Doctrine of the Russian Federation').

${ }^{25}$ On the potential for energy production based on biodegradable waste from the agro-industry in the Kaluga Oblast', see CCGS (n 6) 8-9 and 42-58.

${ }^{26}$ ibid. On the importance of waste (biomass) management for regional renewable energy policies in Europe, see e.g. Commission, 'The Support of Electricity from Renewable Energy Sources' (n 18) 15; Gemma Reece and Max Rathmann, Harmonisation and Coordination of European RES-E Support Mechanisms - Consequences from a National Viewpoint, (Ecofys, 2008) 3 <http://www.futurese.org/docs.php> accessed 3 January 2013.

${ }^{27}$ See European Wind Energy Association, Green Growth - The Impact of Wind Energy on Jobs and the Economy (2012) <www.ewea.org/greengrowth> accessed 3 January 2013; Commission Staff Working Document SWD (2012) 164 final accompanying Commission, 'Renewable energy: a major player in the European energy market' (Communication) COM (2012) 271 final.

${ }^{28}$ On the importance of economic benefits for regional renewable energy policies in Australia and Canada, see Jones (n 17) 10; IEA, Energy Policies of IEA Countries - Canada Review 2009 (2010) 90.

${ }^{29}$ See Valery Minin, Economic Aspects of Small-Scale Renewable Energy Development in Remote Settlements of the Kola Peninsula, Bellona Report 2012, at 41,

<http://www.bellona.org/reports/renewables-economy-kola> accessed 3 January 2013.

${ }^{30}$ See e.g. the case of the Kaluga Oblast' in CCGS (n 6) 38-39.

${ }^{31}$ On the policy objectives underlying renewable energy support schemes in general, see Simon Müller, Adam Brown, and Samantha Ölz, Renewable Energy: Policy Considerations for Deploying Renewables (IEA,

http://www.iea.org/publications/freepublications/publication/name,20553,en.html.
} 
social and political arguments to support the case of renewable energy. ${ }^{32}$ The risk of criticism from the Centre (e.g. because of the sensitivity of energy price increases) might dissuade regional authorities from independent implementation of renewable energy policies, even if these policies could contribute to the economic and social development of the regions concerned. Moreover, corruption and the protection of vested interests could be barriers to achieve the social and economic benefits associated with regional renewable energy policies in Russia.

\subsection{Economies of Scale v. “allocative inefficiency of centralised provision"33}

In the environmental federalism literature, an oft-cited advantage of the centralised approach to environmental protection relates to the economies of scale in regulation. ${ }^{34}$ Proponents of centralisation highlight the benefits that uniform environmental rules provide to industry, particularly in terms of the reduction of transaction costs. ${ }^{35} \mathrm{On}$ the other hand, advocates of a decentralised approach to environmental protection invoke the 'allocative inefficiency of the centralised provision'. ${ }^{36}$ The causes and extent of environmental degradation, as well as the nature and cost of the remediation needed, vary greatly from state to state and therefore justify state-level regulation. ${ }^{37}$

Similar considerations are relevant in assessing the advantages and disadvantages of centralised and decentralised support of renewable energy sources in Russia. On the one hand, a uniform support scheme at the federal level could, in theory, reduce transaction costs for investors. Moreover, a centralised approach presents the benefits of "learning effects" that flow from deploying the technology to meet greater cumulative volume levels'. ${ }^{38}$ On the other hand, given Russia's enormous territory, the physical potential for renewable energy and the economic power to support these investments varies greatly between the different regions of the Russian Federation. ${ }^{39}$ Thus a decentralised policy would be better adapted to these local needs and could therefore be more efficient. ${ }^{40}$

\subsection{Investment Certainty v. Innovation and Flexibility}

\footnotetext{
${ }^{32}$ The author is grateful to Arild Moe for his argument. On the centralisation of power in Russia, see e.g. Cameron Ross, 'Federalism and Inter-government Relations in Russia' (2010) 26 J Communist Studies and Transition Politics 165, 181.

${ }^{33}$ Michael Faure and Jason Scott Johnston, 'The Law and Economics of Environmental Federalism: Europe and the United States Compared' (2008) University of Pennsylvania Law School Institute for Law and Economic Research Paper No. 08-07, 29 <http://papers.ssrn.com/sol3/papers.cfm?abstract_id=1098493> accessed 3 January 2013.

${ }^{34}$ Ann Carlson, 'Iterative Federalism and Climate Change' (2009) 103 Nw U L Rev 1097, 1104; Garrick Pursley and Hannah Wiseman, 'Local Energy’ 60 Emory L J 877, 939.

${ }^{35}$ Sovacool (n 15) 421. See also Commission Staff Working Document) SEC (2008) 57, 15; Renewable Energy Systems Limited, Response to the Consultation on Electricity Market Reform (2011) <www.decc.gov.uk/en/content/cms/consultations/emr/emr.aspx> accessed 3 January 2013.

${ }^{36}$ On this concept and the relevant literature, see Faure and Johnston (n 33$) 29$.

${ }^{37}$ Pursley and Wiseman (n 34) 936.

${ }^{38}$ On this argument generally, see Benjamin Sovacool and Christopher Cooper, 'Big is Beautiful: The Case for Federal Leadership on a National Renewable Portfolio Standard' (2007) 20 The Electricity J $48,57$.

${ }^{39}$ On the potential for renewable energy in the regions of the Russian Federation, see Vladimir Nikolaev and others, Perspektivy razvitiia vozobnovliaemykh istochnikov energii v Rossii - Rezul'taty proekta TASIS (2009); Aleksander Starkov and others, Russian Wind Atlas (Russian-Danish Institute for Energy Efficiency, 2000).

${ }^{40}$ On this argument in the US, see Pursley and Wiseman (n 34) 937.
} 
Advocates of a centralised approach to environmental protection highlight the positive contribution of uniform rules to investment predictability and certainty. Under a centralised approach, 'uniformity helps manufacturers and industry by providing a consistent and predictable statutory environment' ${ }^{41}$ In defence of decentralisation, the literature refers to the contribution by regional authorities to innovation and agendasetting. Regions can serve as 'laboratories' to test different environmental policy instruments ${ }^{42}$ that are later used at federal level. ${ }^{43}$

Investment certainty is, given the capital intensity and long term nature of clean energy investments, a key factor for the deployment of renewable energy sources. ${ }^{44}$ From an investor's perspective, 'a financial change of the support system is considered the most important risk factor' for investors in renewable energy since the level of support is the most important element influencing expected profit. ${ }^{45}$ In Russia this risk is exacerbated by the relative instability and unpredictability of the investment climate, together with the poor protection of property rights and inadequate enforcement of contracts. ${ }^{46}$ The paramount importance of regulatory certainty for renewable energy investments is, given the alleged benefit of uniformity and stability under centralised environmental policies, a strong argument in favour of federal-level support schemes for renewable energy.

In Russia, however, the federal level of government has been reluctant to implement a functioning support scheme for renewable energy, mainly because of the impact that this policy could have on energy prices. ${ }^{47}$ The availability of relatively cheap fossil fuels in Russia reduces the interest of policymakers in the development of alternative modes of electricity production, given the cost of these investments in relation to the high political sensitivity of price increases in the energy sector. More importantly

\footnotetext{
${ }^{41}$ Kristen Engel, 'State Environmental Standard-setting: Is There a "Race" and Is It "To the Bottom?" (1997) 48 Hastings L J 271.

${ }^{4}$ Sovacool (n 15) 430; Kirsten Engel, 'Harnessing the Benefits of Dynamic Federalism in Environmental Law' (2006) 56 Emory LJ 159, 182; Daniel Farber, 'Climate Change, Federalism, and the Constitution' (2008) 50 Arizona LR 879, 922; Alexandra Klass, 'State Innovation and Preemption: Lessons from State Climate Change Efforts' (2008) 41 Loy LALR 1653, 1707.

${ }^{43}$ Sovacool (n 15) 431; Jonathan Adler, 'Judicial Federalism and the Future of Federal Environmental Regulation' Case Research Paper Series in Legal Studies 04-6 (2004) 82 <http://papers.ssrn.com/sol3/papers.cfm?abstract_id=535663 > accessed 3 January 2013; David Vogel and others, 'Environmental Federalism in the European Union and the United States' (2010) Harvard Business School Working Paper 10-085, 2 <http://hbswk.hbs.edu/item/6383.html> accessed 3 January 2013.

44 Mario Ragwitz and others, Interim Report of the Project OPTRES (2006) 77-78 $<$ http://www.optres.fhg.de/> accessed 3 January 2013; Commission, 'The Support of Electricity from Renewable Energy Sources' (n 18) 16-17.

${ }^{45}$ Ragwitz (n 44) 77; Commission, 'The Support of Electricity from Renewable Energy Sources' (n 18) 16-17.

${ }^{46}$ Klaus Schwab (ed), Global Competitiveness Report 2009-2010 (World Economic Forum, 2009) 27, 268 <www.weforum.org> accessed 3 January 2013; European Commission Directorate-General for Economic and Financial Affairs, ECFIN Country Focus - Foreign Investment in Russia (2008) <http://ec.europa.eu/economy_finance/publications/publication10969_en.pdf> accessed 3 January 2013.

${ }^{47}$ According to the IEA (n 1) 326, '[v]arious schemes are under discussion but, against a background of concern about high end-user electricity prices, the government appears reluctant for the moment to add higher costs into the wholesale mix by agreeing to include a premium in tariffs for new renewablebased electricity.' See also IFC, Renewable Energy Policy in Russia (n 1) 26.
} 
from a perspective of investment certainty, the federal approach to the support of renewable energy has undergone substantial changes. ${ }^{48}$ The Federal Electricity Law, as amended in November 2007, established the basis for a 'premium' scheme - a regulated mark-up to the wholesale market price. ${ }^{49}$ In 2010 , the Law was eventually amended to provide a legal basis for the support of renewable energy on the basis of long term regulated capacity agreements. ${ }^{50}$ That notwithstanding, in 2012, the Government still had to adopt key documents to ensure the functioning of this new capacity-based approach to the support of renewable energy. ${ }^{51}$

In the absence of action at the federal level, regional initiatives are necessary to innovate and test renewable energy support schemes and thereby influence the federal agenda. Several regions of the Russian Federation (e.g. Belgorod, ${ }^{52}$ Tomsk Oblast', ${ }^{53}$ Krasnodar, ${ }^{54}$ Amur Oblast', ${ }^{55}$ Volvograd Oblast ${ }^{56}$ and Chelyabinsk ${ }^{57}$ ) have adopted regional legislation to promote the development of renewable energy sources. Following the environmental federalism literature, these initiatives demonstrate the role that regions could play as 'laboratories' and sources of innovation.

\subsection{Race to the Bottom v. Race to the Top}

Renewable energy support policies - in a similar way to energy efficiency improvement policies - present both costs and benefits for the regional economy. ${ }^{5}$ On the one hand, the deployment of renewable energy reduces local pollution and waste, creates employment, stimulates innovation and contributes to regional energy

\footnotetext{
${ }^{48}$ IFC, Renewable Energy Policy in Russia (n 1) 59.

${ }^{49}$ On the premium scheme, see Anatole Boute, 'A Comparative Analysis of the European and Russian Support Schemes for Renewable Energy: Return on EU Experience for Russia' (2011) 4 J of World Energy L and Business 157.

${ }^{50}$ On the capacity-based scheme, see Anatole Boute, 'Promoting Renewable Energy through Capacity Markets: An Analysis of the Russian Support Scheme' (2012) 46 Energy Policy 68.

${ }^{51}$ It must be noted that, on 21 November 2012, the Ministry of Energy presented a proposal of implementation of the capacity scheme for approval by the Government of the Russian Federation. See Proekt rasporiazheniia Pravitel'stva RF ' $O$ vnesenii izmenenii v Osnovnye napravleniia gosudarstvennoi politiki v sfere povysheniia energeticheskoi effektivnosti elektroenergetiki na osnove ispol'zovaniia vozobnovliaemykh istochnikov energii na period do 2020 goda, utverzhdennye rasporiazheniem Pravitel'stva RF ot 8 ianvaria 2009 g. No. 1-r', <http://minenergo.gov.ru/documents/razrabotka/> accessed on 10 January 2013.

${ }^{52}$ Resolution of the Government of the Belgorod Oblast' on the Approval of Eco-tariffs in the Electricity Sector.

53 Zakon Tomskoi Oblasti 'O ispol'zovanii lokal'nykh netraditsionnykh vozobnovliaemykh istochnikov energii v Tomskoi oblasti’, No. 55-OZ, signed 1 December 2000.

54 Zakon Krasnodarskogo Kraia ob ispol'zovanii vozobnovliaemykh istochnikov energii v Krasnodarskom krae, No. 723-KZ, signed 7 June 2004.

55 Zakon Amurskoi oblasti o razvitii netraditsionnykh vozobnovliaemykh istochnikov energii $\mathrm{v}$ Amurskoi oblasti, No. 451-OZ, signed 14 March 2005.

${ }^{56}$ Rasporiazhenie Administratsii Volgogradskoi oblasti O konkurse po vynory istochnika al'ternativnoi energetiki, No. 10-r, signed 5 January 1995.

${ }^{57}$ Postanovlenie Pravitel'stva Cheliabinskoi oblasti 'Ob oblastnoi tselevoi programme povysheniia energeticheskoi effektivnosti ekonomiki Cheliabinskoi oblasti i sokrashcheniia energeticheskikh izderzhek v biudzhetnom sektore na 2010-2020 gody', with amendments, No. 324-P, 17 December 2009.

${ }^{58}$ See Lincoln Davies, 'State Renewable Portfolio Standards: is there a "Race" and is it "to the Top?" 3 San Diego J Climate \& Energy L 3, 46; Barry Rabe, 'Race to the Top: The Expanding Role of U.S. State Renewable Portfolio Standards' (2007) 7 Sustainable Development L and Policy 10; Engel, 'State Environmental Standard-setting' (n 41) 375.
} 
security. These economic and environmental benefits present worthy reasons for states to compete with each other to attract capital and technology in the renewable energy sector, thereby stimulating a 'race to the top' in terms of the ambition of regional support policies.

On the other hand, renewable energy policies impose a cost on energy end-users, an issue of particular political sensitivity in Russia. At least in the short-term, the additional public support necessary to finance the relatively high capital cost of investment in renewable energy will generate increased electricity prices. Moreover, because of their variable production patterns, the connection of wind and solar PV installations to the grid can result in additional network reinforcement and system balancing charges. This negative impact on the regional economy could act as deterrent to regional renewable energy support policies. In regions with a limited renewable energy resource base or abundance of fossil fuels, this economic impact is, in the short term, more likely to outweigh the benefits of renewable energy policies than in energy importing regions. In Russia, where the Unified Energy System transcends regional boundaries, unilateral renewable energy action by activist regions could, in the short term, increase electricity prices and thereby disadvantage local industrial and commercial costumers who might then be tempted to move to neighbouring states. ${ }^{59}$ However, this risk of industry relocation could be offset by the employment and innovation benefits of a local renewable energy industry, as well as by the positive contribution that the deployment of renewable energy sources can have on regional energy security.

\subsection{Renewable Energy Federalism in Russia: the Key Role of Regions}

An analysis of renewable energy in Russia, in the light of the environmental federalism literature, raises doubts regarding the current feasibility and short-term effectiveness of federal support to develop clean energy. Arguments usually invoked in favour of a centralised approach to environmental protection are weak when it comes to the promotion of renewable energy in Russia. First, climate change is not a high political priority; federal support for renewable energy can thus not easily be justified on the basis of its effectiveness to achieve global emission reductions. In addition, the argument that a centralised approach to environmental protection leads to improved investment certainty and reduced transaction costs is less obvious in Russia. The federal government has introduced substantial changes to its renewable energy policy (from a premium to a capacity-based scheme) and, given the political sensitivity of price increases, has been reluctant to implement a functioning support scheme.

In contrast, action at regional level appears, at least for the time being, to present higher efficiency gains for the promotion of clean energy in Russia. Given the very diverse renewable energy resource bases found in the different regions of the Russian Federation, regional authorities might be better equipped to develop support mechanisms that are best adapted to their specific conditions. Regional action to support renewable energy could also be more efficient because of the local environmental and economic benefits of this policy, particularly with regard to the

\footnotetext{
${ }^{59}$ Robert McKinstry and Thomas Peterson, "The Implications of the New "Old" Federalism in ClimateChange Legislation: How to Function in a Global Marketplace When States Take the Lead' (2007) 20 Pac McGeorge Glbal Bus \& Dev LJ 61, 64.
} 
solution that it provides for the treatment of waste and opportunities in terms of employment, innovation, security of supply and modernisation of the energy infrastructure. Taking these local benefits into account, regions could act as 'laboratories' or 'regulatory safety nets ${ }^{60}$ waiting for federal action. Innovation with renewable energy policies at regional level could ultimately help overcome federal quasi-paralysis in this field. There is however a risk that, given the centralisation of power in Russia, regions might be reluctant to promote renewable energy sources if such initiatives face the risk of criticism by the federal authorities.

In this context, it is 'paramount that states [regions] are given relatively free reign to develop policy solutions ${ }^{61}$ within the boundaries of federal law. The risk of federal rules 'closing the door to the policy-making efforts of other levels of government ${ }^{\text {' }}$ should be avoided. A crucial question is thus whether, in Russia, the federal framework governing the electricity sector and renewable energy provides regions with sufficient scope to implement ambitious renewable energy policies. In particular, do regions have the regulatory power to provide long term regulated tariff guarantees to stimulate investment in electricity production from renewable energy sources?

\section{Regional Powers for the Promotion of Renewable Energy Sources in Russia}

To determine whether regions in Russia have sufficient regulatory powers to promote renewable energy, it is necessary to look at the constitutional division of powers between regions and the federal level of government, before examining how renewable energy and electricity tariffs are regulated in the Russian Federal Electricity Law and the Federal Energy Efficiency Law.

\subsection{Constitutional Division of Powers}

The Russian Constitution ${ }^{63}$ establishes the federal nature of Russia's state system. The Russian Federation consists of 21 Republics, nine 'Krais', 47 'Oblasts', four autonomous 'Okrugs', and two cities of federal importance (Moscow and St Petersburg). ${ }^{64}$ These 'subjects' of the Russian Federation exercise state authority within the limits of the constitutional division of powers between the federal and regional (subject) levels of government. ${ }^{65}$ As a general rule, regional authorities benefit from residual powers, ${ }^{66}$ i.e. they have the competence to regulate on all issues that have not been allocated to the federal level of government or to both the federal and the regional authorities (the so-called 'shared competences'). ${ }^{67}$ When exercising

\footnotetext{
${ }^{60}$ Engel, 'Harnessing the Benefits of Dynamic Federalism in Environmental Law' (n 42) 178. See also Erwin Chereminsky, 'Empowering States: The Need to Limit Federal Preemption' (2005) 33 Pepp LR 69, 74; Kevin Doran, 'Can the U.S. Achieve a Sustainable Energy Economy from the Bottom-Up?: An Assessment of State Sustainable Energy Initiatives’ (2006) 7 Vt J Envtl L 95, 107.

${ }^{61}$ Engel, 'Harnessing the Benefits of Dynamic Federalism in Environmental Law' (n 42) 181.

62 ibid.

${ }^{63}$ Konstitutsiya Rossiiskoi Federatsii, prinyata vsenarodnym golosovaniem, 12 December 1993, with subsequent amendments.

${ }^{64}$ Russian Constitution, Art 65, para 1.

${ }^{65}$ Nadezhda Mikhaleva, Konstitutsii i ustavy sub"'ektov Rossiskoi Federatsii: sravnitel'no-pravovoe issledovanie (Iurkompani, 2010), at 119, accessed via Konsul'tantPlius on 1 September 2012.

${ }^{66}$ Evgenii Pershin and Milena Gligich-Zolotareva, 'Aktual'nye voprosy razgranicheniia kompetentsii mezhdu Rossiiskoi Federatsiei i sub' 'ektami Rossisskoi Federatsii' (2008) 2 Gosudarstvennaia vlast' i mestnoe samoupravlenie 1, accessed via Konsul'tantPlius on 1 September 2012.

${ }^{67}$ Russian Constitution, art 73.
} 
'shared competences', regional authorities can regulate certain activities up until the federal level decides to intervene (pre-empt). If a region has acted in the absence of federal regulation, it will have to put its regional law into conformity with federal law.

It is important to note that, according to Article 4 of the Russian Constitution, the Constitution and federal laws are the supreme law of the Russian Federation. In accordance with Article 1 of Federal Law 184-FZ on the General Principles for the Organisation of the Legislative and Executive Organs of the Subjects of the Russian Federation, ${ }^{68}$ federal laws prevail in any case of conflict with regional acts. ${ }^{69}$

The following competences are of relevance for renewable energy. In accordance with Article 71 of the Russian Constitution, the federal authorities have the exclusive competence to regulate the federal energy systems and nuclear energy. ${ }^{70}$ The federal authorities are also in charge with the regulation of the internal (single) market, i.e. the exchange of goods within the Russian Federation. Moreover, they hold the power to determine federal policy on economic development and environmental protection. Furthermore, Article 72 of the Constitution establishes shared federal-regional competences for the regulation of environmental protection and ecological security.

These competences can be interpreted in a broad way ${ }^{71}$ and accordingly provide extensive powers to the federal government. ${ }^{72}$ This is essentially what has happened in recent years ${ }^{73}$ and has led to the centralisation of powers in the Russian Federation, ${ }^{74}$ including tariff and electricity regulation, ${ }^{75}$ with important consequences for the ability of regional authorities to pursue independent renewable energy policies.

\footnotetext{
${ }^{68}$ Federal'nyi zakon RF 'Ob obshchikh printsipakh organizatsii zakonodatel'nykh (predstavitel'nykh) i ispolnitel'nykh organov gosudarstvennoi vlasti sub'"ektov RF', with subsequent amendements, Sobranie Zakonodatel'stva Rossiiskoi Federatsii (SZ RF) (18 October 1999) No. 42 item 5005.

${ }^{69}$ Opredelenie Verkhovnogo syda Rossiiskoi Federatsii, No. 58-G08-18, 29 October 2008. See also Mikhaleva (n 65) 19.

${ }^{70}$ See Anna Vishniakova, Publichnaia Reglamentatsiia Otnoshenii na Optovom Rynke Elektricheskoi Energii i Moshchnosti (Institut Energeticheskogo Prava Moskovskoi Gosudarstvennoi Iuridicheskoi Akademii Imenii Kutafina, 2012) 46.

${ }^{71}$ See Daniel Kempton, 'Three Challenges to Assessing Russian Federalism' in Daniel Kempton and Terry Clark (eds) Center-Periphery Relations in the Former Soviet Union - Unity or Separation (Praeger, 2002) 13, 41, noting that '[ $\mathrm{t}]$ he list of powers included in Arts 71 and 71 is so extensive that the obvious question is what meaningful powers are left for the subetky? Probably very few.'

${ }^{72}$ See Vishniakova (n 70) 47; N. Mikhailov, 'Printsipy i Metody Razdeleniia Polnomochii mezhdu Rossiiskoi Federatsiei i ee Sub' 'ektami v Sfere Energosnabzheniia' 4 (2006) Predprinimatel'skoe Pravo (accessed through Konsul'tantPlius on 10 January 2013).

${ }^{73}$ It is important to note that the centralisation of powers, particularly regarding environmental protection, is relatively recent. As noted in OECD, Environmental Policy and Regulation in Russia The Implementation Challenge (2006) 11, in 2000, most of the responsibility for environmental protection was devolved to the regional level of government. Analysts noted in this respect that this devolution of powers to the regional level could be seen as a way for the federal level of government to downscale environmental management (see World Bank, Environmental Management in Russia: Status, Directions and Needs (2004) <http://www.oecd.org/env/outreach/35486874.pdf > accessed 3 January 2013) or pass on responsibilities for issues that it could not solve (see Vladimir Gel'man, 'Leviathan's return - The policy of recentralisation in contemporary Russia' in Cameron Ross and Adrian Campbell (eds), Federalism and Local Politics in Russia (Routledge, 2009) 1, 5; Olga Aksenova, 'Tsentralizatsiia Vlasti, Lokalizatsiia Ekologicheskoi Politiki' (2007) Sotsiologicheskie Issledovaniia 8.

${ }^{74}$ See Ross (n 32) 181; Elena Chebankova, 'Adaptive Federalism and Federation in Putin's Russia' in (2008) 60 Europe-Asia Studies 989, 993; Paul Goode, 'The Fall and Rise of Regionalism?' (2010) 26 J Communist Studies and Transition Politics 233, 238.
} 


\subsection{Federal Regulation of the Electricity Sector}

The electricity sector is a particularly illustrative example of the centralisation of powers at the federal level. The Russian electricity system - the Unified Energy System of the Russian Federation - is the world's fourth largest electricity system. It covers a vast region that extends from Russia's borders with the European Union to the Pacific Ocean. To maintain the unity of the system, Russian electricity regulation is based on a unified (all-Russia) approach. ${ }^{76}$ The Federal Electricity Law 'pre-empts' regulation in the electricity sector. In accordance with Article 4 of the Law, regional authorities cannot adopt legislation affecting the electricity sector unless explicitly permitted to do so by federal law. As will be discussed in the next sub-section, an essential competence that the Federal Electricity Law delegates to regional authorities is the power to adopt tariffs for the RES-E that network companies purchase to compensate the losses on their network. Moreover, regions could act based on the broader powers conferred by the Federal Energy Efficiency Law. Indeed, as will be discussed below, this Law includes renewable energy within the concept of energy efficiency. It mandates regions to impose energy efficiency (e.g. renewable energy) obligations on network companies and gives regions the power to adopt tariffs that facilitate energy savings, e.g. through the use of renewable energy.

\subsection{Renewable Energy under the Federal Electricity Law}

The Federal Electricity Law ${ }^{77}$ charges the Government of the Russian Federation with the task of determining national policy on renewable energy. The Law does not limit this task to the determination of renewable energy policy at the federal level. The task therefore implicitly extends to cover the determination of regional renewable energy policy. Federal regulation of renewable energy sources, including the promotion of renewable energy in regions of the Russian Federation, finds constitutional support in Article 72 of the Russian Constitution that establishes shared powers for environmental protection.

According to the Federal Electricity Law, a key aspect of the national renewable energy policy is the determination of strategic targets and measures (including, in particular, support schemes) to achieve these targets. To monitor the achievement of these strategic targets, the Law establishes a system of qualification (i.e. certification) of renewable energy generating facilities. The Federal Electricity Law charges the regulator of the wholesale market, the Market Council, with the task of managing this process of qualification. ${ }^{78}$ Qualification is a cornerstone of Russian renewable energy law: support based on the Federal Electricity Law is limited to 'qualified' installations.

As mentioned above, in January 2009, the Government of the Russian Federation has adopted a 4.5 per cent target of electricity consumption and production from renewable energy sources to be achieved by 2020. Moreover, the Government has adopted different programs of measures, outlining how it intends to achieve this

\footnotetext{
${ }^{75}$ See Gel'man (n 73) 17.

${ }^{76}$ See arts 4 and 6 of the Federal Electricity Law.

77 art 21, para 1.

78 art 33, para 3.
} 
target. ${ }^{79}$ These programs have rarely been implemented and have not led to a functioning support scheme for renewable energy. They thereby raise serious doubts as to whether the 4.5 per cent target can be achieved by 2020 and as to whether it should be postponed to 2030 .

Nonetheless, the Federal Electricity Law mandates the Government to support the use of renewable energy. The Law establishes the basis for a 'premium' scheme (mark-up in addition to the wholesale market price). In 2010, a new approach to the support of renewable energy was included in the Federal Electricity Law: the Law now provides a legal basis for the support of renewable energy through the capacity market. The capacity-based support scheme did not formally replace the premium scheme. In practice, however, it seems increasingly clear, that the premium scheme is unlikely to see the light of day with all focus now being on the development of the capacitybased scheme.

With the premium and capacity-based schemes, the Federal Electricity Law integrates support for renewable energy into the wholesale market. It is logical for a federal law to follow this approach since the wholesale market is the trading platform which brings together market players of federal importance - in particular, large electricity producers (with an installed capacity exceeding $5 \mathrm{MW}$ ) and large consumers. The Federal Electricity Law requires the Government of the Russian Federation to develop the necessary regulatory framework to implement these support schemes in practice. Although the Government of the Russian Federation has adopted different legislation that outlines how parts of these support schemes would function, important parts of the regulatory framework are still missing. Investors still have no idea of the level and duration of support that these renewable energy installations will receive. In the absence of the necessary implementing legislation, federal support through the wholesale market is impossible. Continuous delays and postponements in the implementation of a functioning support scheme highlight the political sensitivity of renewable energy at the federal level of government in Russia. The Government has invoked technical and legal obstacles to justify the delay in the implementation of the support scheme. ${ }^{80}$ More importantly, renewable energy in Russia faces opposition because of the short-term impact that this policy can have on electricity prices. ${ }^{81}$

The Federal Electricity Law does not limit support for renewable energy to federal mechanisms on the wholesale market. It also establishes a legal basis for support on the retail market, i.e. for renewable energy generating facilities with an installed capacity under $25 \mathrm{MW}$. In particular, the Law establishes an obligation for network companies to compensate losses on their network as a priority by purchasing RES-

\footnotetext{
${ }^{79}$ See, most recently, Rasporiazhenie Pravitel'stva RF 'Ob utverzhdenii kompleksa mer stimulirovaniia proizvodstva elektricheskoi energii generiruiushchimi ob' ektami, funktsioniruiushchimi na osnove ispol'zovaniia vozobnovliaemykh istochnikov energii, No. 1839-r, signed 4 October 2012, Sobranie Zakonodatel'stva Rossiiskoi Federatsii (SZ RF) (8 October 2012) N 41 item 5671 (hereinafter the 'Government Resolution No. 1839-r on Measures to Promote Renewable Energy Sources').

${ }^{80}$ See Minenergo, Poiasnitel'naia zapiska k proektu rasporiazheniia Pravitel'stva RF ob utverzhdenii kompleksa mer stimulirovaniia proizvodstva elektricheskoi energii generiruiushchimi ob' ektami, funktsioniruiushchimi na osnove ispol'zovaniia vozobnovliaemykh istochnikov energii (10 February 2012), <http://minenergo.gov.ru/documents/razrabotka/9989.html> accessed 3 January 2013 (hereinafter the 'Explanatory Note of the Ministry of Energy to the Project of Resolution on Measures to Promote Renewable Energy').

${ }^{81}$ See IEA (n 1) 326.
} 
E. ${ }^{82}$ On the retail market, regional tariff authorities (Regional Energy Commissions) can regulate the price at which network companies purchase RES-E to compensate their losses. ${ }^{83}$ By basing support on regulated prices and imposing a purchase obligation on network companies, this scheme resembles 'feed-in tariffs' ${ }^{84}$ In Russia, the competence to adapt RES-E tariffs is one of the rare powers that the Federal Electricity Law delegates to regional authorities. However, as will be shown in detail below, the implementation of this regional scheme faces not insignificant regulatory barriers at federal level.

\subsection{Constitutional Status of Regional Tariff Authorities}

Regional tariff authorities play a central role in regional renewable energy policies, since they are responsible to determine the price at which network companies purchase RES-E. It is therefore important to examine the structure of these authorities and, in particular, the extent to which these entities are dependent on the federal government.

Article 77 of the Russian Constitution charges regional authorities with the task of independently establishing the structure of the regional administration. However, those authorities must respect the general principles for the organisation of the executive branch of government, which are set out in federal laws. This administrative structure results from the principle of the unified system of administration across the Russian Federation. ${ }^{85}$ In accordance with the Federal Law on the General Principles for the Organisation of the Legislative and Executive Organs of the Regions of the Russian Federation, tariff regulation is one of the competences shared between the federal and regional levels of government. The federal authorities, based on their right of pre-emption of shared powers, have made use of this competence: the Federal Electricity Law and the Decree of the Government of the Russian Federation No. 1178 on Electricity Retail Tariffs ${ }^{86}$ govern the activities of the tariff authorities in the Russian electricity sector. Moreover, the administrative functioning of regional tariff authorities is regulated by the Decree of the Government of the Russian Federation on the Regulation of the Regional Tariff Authorities. ${ }^{87}$ This governmental Decree determines the main tasks and powers of the regional tariff authorities and regulates the procedure for the formation of tariffs. This federal regulatory framework thus limits the margin for manoeuvre of regional tariff authorities.

\footnotetext{
${ }^{82}$ Federal Electricity Law, art 32, para 3.

${ }^{83}$ Federal Electricity Law, art 23.1, para 3.

${ }^{84}$ These are the most commonly used type of support scheme around the world consisting in the guarantee of a regulated price for the electricity output from renewable energy installations.

${ }^{85}$ Mikhaleva (n 65) 114.

${ }^{86}$ Postanovlenie Pravitel'stva Rossiiskoi Federatsii 'O tsenoobrazovanii v oblasti reguliruemykh tsen (tarifov) v elektroenergetike', with subsequent amendments, No. 1178, signed 29 December 2011, Sobranie Zakonodatel'stva Rossiiskoi Federatsii (SZ RF) 23 January 2012 No. 4 item 504 (hereinafter the 'Government Decree No. 1178 on Electricity Retail Tariffs').

${ }^{87}$ Postanovlenie Pravitel'stva Rossiiskoi Federatsii 'Ob utverzhdenii tipovogo polozheniia ob organe ispolnitel'noi vlasti Sub' 'ektka Rossiiskoi Federatsii v oblasti gosudarstvennogo regulirovaniia tarifov', with subsequent amendments, No. 97, signed 21 February 2011, Sobranie Zakonodatel'stva Rossiiskoi Federatsii (SZ RF) (7 March 2011) No. 10 item 1379 (hereinafter the 'Government Decree on Regional Tariff Authorities').
} 
In accordance with this regulatory framework, the Federal Service for Tariffs (FST) is the highest tariff authority in the Russian Federation. ${ }^{88}$ It is charged with the development of methodologies that govern the regulation of tariffs at regional level. In the electricity sector, regional tariff authorities regulate prices on the basis of Order 20-e/2 of the FST. ${ }^{89}$ Moreover, the FST adopts limits (minimum and maximum prices) within which regional tariffs must remain.

Importantly for present purposes, the Government Decree on the Regulation of Regional Tariff Authorities allows regional authorities to adopt RES-E tariffs. More generally, this Decree provides that one of the main tasks of regional tariff authorities is to create economic incentives to stimulate energy efficiency improvements in the electricity sector, including, as will be discussed in the next sub-section, the use of renewable energy sources. ${ }^{90}$ Regional tariff authorities thus have a clear mandate to adopt tariffs that provide economic stimulus to develop renewable energy. However, these tariffs must remain within the limits established by the FST.

\subsection{Renewable Energy as part of the Russian Energy Efficiency Strategy}

The Federal Energy Efficiency Law includes renewable energy in the Russian energy efficiency strategy: ${ }^{91}$ the deployment of renewable energy is one of the energy efficiency improvement measures that regions should consider for inclusion in regional energy efficiency programs - the programs that outline how regions intend to improve the energy efficiency of the regional economy. ${ }^{92}$ Moreover, the energy efficiency targets that regions must adopt in accordance with the Federal Energy Efficiency Law should reflect the deployment of renewable energy sources. ${ }^{93}$ The Federal Energy Efficiency Law thus provides additional legal support for regional action to promote the use of renewable energy. ${ }^{94}$ This legal basis is an important means of overcoming the federal obstacles that currently inhibit regional RES-E tariff initiatives under the Federal Electricity Law.

\footnotetext{
${ }^{88}$ Postanovlenie Pravitel'stva Rossiiskoi Federatsii 'Ob utverzhdenii polozheniia o Federal'noi Sluzhbe po Tarifam', with subsequent amendments, No. 332, signed 30 June 2004, Sobranie Zakonodatel'stva Rossiiskoi Federatsii (SZ RF) (15 July 2004) No. 29 item 3049 (hereinafter the 'Government Resolution on the Federal Service for Tariffs').

${ }^{89}$ Prikaz FST RF ' Ob utverzhdenii metodicheskikh ukazanii po raschetu reguliruemykh tarifov i tsen na elektricheskuiu (teplovuiu) energiiu na roznichnom (potrebitel'skom) rynke', with subsequent amendments, No. 20-e/2, signed 6 August 2004, Rossiiskaia gazeta (2 November 2004) No. 242 (hereinafter 'Order of the FST 20-e/2 on Tariff Methodologies in the Electricity Retail Market').

${ }^{90}$ The Government Decree on Regional Tariff Authorities, item 3, d.

${ }^{91}$ See IFC, Financing Renewable Energy Investments in Russia: Legal Challenges and Opportunities (2012)

<www1.ifc.org/wps/wcm/connect/region__ext_content/regions/europe+middle+east+and+north+africa /ifc+in+europe+and+central+asia/publications/financing+renewable+energy+investments+in+russia++legal+challenges+and+opportunities> accessed 3 January 2013.

${ }^{92}$ See also Postanovlenie Pravitel'stva Rossiiskoi Federatsii 'O trebovaniiakh k regional'nym I munitsipal'nym programmam $\mathrm{v}$ oblasti energosberezheniia I povysheniia energeticheskoi effektivnosti', No. 1225, signed 31 December 2009, with subsequent amendments, Sobranie Zakonodatel'stva Rossiiskoi Federatsii (SZ RF) (8 February 2010) No. 6 item 645 (hereinafter the 'Government Decree On Requirements for the Regional and Municipal Energy Efficiency Programs'). ${ }^{93}$ Federal Energy Efficiency Law, art 14, para 5.

${ }^{94}$ Vladimir Popondopulo, Oleg Gorodov and Dmitrii Petrov, 'Vozobnovliaemye Istochniki Energii v Elektroenergetike, (2011) Energeticheskoe Pravo, at 4 (access through Konsul'tantPlius on 10 January 2013).
} 


\section{Federal Barriers to Regional Renewable Energy Tariff Policies}

Initiatives by regional authorities to guarantee the purchase of RES-E at regulated prices face obstacles which stem from the division of powers in the electricity sector between the federal and regional levels of government. Regional RES-E tariffs can be blocked by federal control over electricity prices and by federal refusal to qualify renewable energy installations. In the absence of a functioning support scheme at national level, these federal obstacles to regional policies could hinder, and even paralyse, the development of renewable energy in Russia. From a clean energy perspective, an analysis of these obstacles and ways to overcome them is therefore essential to understand the scope that regional authorities have to stimulate the use of alternative energy sources in their electricity system.

\subsection{Qualification of Renewable Energy Installations}

The Federal Electricity Law limits the support of renewable energy in Russia to generating facilities that have been 'qualified' as 'renewable energy' installations. Qualification takes place in accordance with the procedure established by Decree of the Government of the Russian Federation No. 426 of 3 June 2008 on the Qualification of a Production Installation Using Renewable Energy Sources. ${ }^{95}$ As outlined above, the qualification of electricity generating facilities as 'renewable energy installations' is a federal competence delegated to the Market Council, the regulator of the wholesale market. ${ }^{96}$ Regional tariff authorities can thus only adopt RES-E tariffs following qualification by the Market Council of the renewable energy installations to which these tariffs will apply.

In accordance with Decree 426 on the Qualification of Renewable Energy Installations, renewable energy projects can only be qualified after their construction and connection to the network. Because of this ex post facto qualification procedure, investors have no guarantee that they will be able to benefit from RES-E tariffs when they make their investment decisions. ${ }^{97}$ Given that regional tariff authorities cannot adopt RES-E tariffs in the absence of qualification, investors have no certainty about the tariff level that will apply to their projects, which exposes them to considerable investment unpredictability. ${ }^{98}$

The risk that the inaction or refusal of federal authorities (i.e. the Market Council) represents for regional RES tariff policies is illustrated by the Decision of the Arbitration Court of the Vologda Oblast', ${ }^{99}$ which was upheld on appeal to the

\footnotetext{
95 Postanovlenie Pravitel'stva Rossiiskoi Federatsii 'O Kvalifikatsii generiruiushchego ob' ekta, funktsioniruiushchego na osnove ispol'zovaniia vozobnovliaemykh istochnikov energii', with subsequent amendments, No. 426, signed 3 June 2008, Sobranie Zakonodatel'stva Rossiiskoi Federatsii (SZ RF) (09 June 2006) No. 23 item 2716 (hereinafter the 'Government Decree on the Qualification of a Production Installation Using Renewable Energy Sources”).

${ }^{96}$ Federal Electricity Law, art 33, para 3.

${ }^{97}$ See IFC, Financing Renewable Energy Investments in Russia (n 91) 11.

${ }^{98}$ The Ministry of Energy has explicitly recognised this problem. See Explanatory Note of the Ministry of Energy to the Project of Resolution on Measures to Promote Renewable Energy.

${ }^{99}$ Reshenie Arbitrazhnogo Suda Vologodskoi Oblasti No. A13-1398/2011, 12 July 2011 (hereinafter 'Decision of the Arbitrazh Court of the Vologda District No. A13-1398/2011').
} 
Federal Arbitration Court of the North-West Circuit, ${ }^{100}$ in a challenge against the validity of RES-E retail tariffs for a facility producing electricity and heat from wood waste. The courts, both at first instance and on appeal, held that the regional tariff authority contradicted the Federal Electricity Law because it adopted a RES-E tariff without qualification of the generating facility concerned in accordance with the appropriate procedure. The court accordingly declared the regional RES-E tariff invalid.

\subsection{Tariff Methodologies}

As examined above, tariff regulation is a competence shared between the federal and regional levels of government. ${ }^{101}$ Regional authorities accordingly have the right to adopt tariffs without the need for a specific mandate under federal law. However, following the principle of supremacy of federal law, regional tariffs must comply with the federal regulation on tariffs. The Federal Electricity Law ${ }^{102}$ regulates the distribution of competences for tariff regulation between the federal and regional level of government: regional authorities must adopt tariffs on the basis of federal tariff principles. ${ }^{103}$ The Russian Government has laid out these principles in Decree No. 1178 on Electricity Retail Tariffs. The Federal Service for Tariffs has, on the basis of these principles, elaborated tariff methodologies in its Order 20-e/2.

With specific reference to renewable energy, Decree No. 1178 on Electricity Retail Tariff confirms that regional tariff authorities must adopt tariffs for the compensation of losses with RES-E following the methodologies determined by the FST. The Government has explicitly mandated the FST with the task of developing specific methodologies for RES retail tariffs. ${ }^{104}$ The FST has not yet adopted these methodologies. The question is therefore whether, in the absence of federal methodologies, regional authorities can independently act and adopt RES retail tariffs on the basis of existing (non RES-specific) methodologies.

It is arguable that making use of existing federal tariff methodologies does not contradict the requirement of Decree No. 1178 on Electricity Retail Tariffs. Indeed, this Decree does not explicitly require the adoption of specific renewable energy tariff methodologies. It only states that renewable energy tariffs must be determined on the basis of federal methodologies.

\footnotetext{
${ }^{100}$ Postanovlenie Federal'nogo Arbitrazhnogo Suda Severo-Zapadnogo Okruga No. F07-8429/11, 31 October 2011 (hereinafter 'Decision of the Federal Arbitrazh Court of the North-West District No. F07-8429/11').

${ }^{101}$ Federal Law on the General Principles for the Organisation of the Legislative and Executive Organs of the Regions of the Russian Federation, art 26.3, para 2, item 55.

${ }^{102}$ See Federal Electricity Law, arts 23 and 24.

${ }^{103}$ This situation differs from a scenario where there would be no federal law. It also differs from the scenario where the applicable federal level explicitly transfers the relevant competence (e.g. determination of methodology and tariff) to the regional authorities. See e.g. Opredelenie Verkhovnogo Suda RF, No. 93-G08-19, 26 November 2008 (hereinafter 'Decision of the Supreme Court of the Russian Federation No. 93-G08-19') (case concerning the regulation of the activities of the guaranteeing supplier in the Magadan Oblast').

${ }^{104}$ Government Resolution No. 1839-r on Measures to Promote Renewable Energy Sources item 4.
} 
Order $20-\mathrm{e} / 2$ of the FST (and Russian tariff regulation in general) ${ }^{105}$ is based on the principle of the 'economic well-founded nature of costs'. Following this principle, investors must demonstrate that their investment and operating costs are justified, such as on the basis of accounting reports, statistical data and / or independent expert evaluations. ${ }^{106}$ Regional authorities could, in the absence of specific RES tariff methodologies, base their tariff decisions on an assessment of the economically wellfounded nature of the costs of the RES investments concerned. In this respect, the relatively higher capital costs of RES investments in relation to thermal power plants could be a challenge. This challenge is, however, not insurmountable. Indeed, the Federal Arbitrazh Court of the North-West District recently recognised that the additional costs related to the transformation and supply of biomass for combined electricity and heat production were, in that case, 'economically well-founded., 107

Nevertheless, from an investor's perspective, the possible adoption of federal RES tariff methodologies by the FST represents a not insignificant risk and could be considered as a critical source of investment uncertainty. ${ }^{108}$ Given the political concern surrounding the cost of renewable energy, we cannot rule out the possibility that the FST or the Ministry of Energy might decide to cap the capital costs and return on investments of RES projects, thereby jeopardising the business case made on the basis of previous regional RES tariff decisions and on which existing investments were made. $^{109}$

\subsection{Federal Tariff Limits}

The price that network companies charge in order to compensate their losses is one of the parameters that regulatory authorities must take into account when determining transmission/network tariffs. ${ }^{110}$ The value of this parameter (i.e. the prices/tariffs at which the electricity to compensate the losses will be purchased) is calculated before

\footnotetext{
${ }^{105}$ Presidium Vysshego Arbitrazhnogo Suda Rossiiskoi Federatsii, Postanovlenie No. 15741/10, 19 April 2011. See also I. A. Leont'ev, Kommentarii k Federal'nomu Zakonu ot 14 Aprelia 1995 goda No. 41-FZ 'O Gosudarstvennom Regulirovanii Tarifov na Elektricheskuiu i Teplovuiu Energiiu v Rossiiskoi Federatsii' (Konsul'tantPlius, 2007) 15.

${ }^{106}$ For recent examples, see Postanovlenie Federal'nogo Arbitrazhnogo Suda Ural'skogo Okruga No. F09-1088/12, 15 March 2012 (hereinafter the 'Decision of the Federal Arbitrazh Court of the Ural District No. F09-1088/12'); Postanovlenie Federal'nogo Arbitrazhnogo Suda Povolzhskogo Okruga No. F06-8306/11, 11 October 2011 (hereinafter the 'Decision of the Federal Arbitrazh Court of the Povolzhski District No. F06-8306/11'); Postanovlenie Federal'nogo Arbitrazhnogo Suda SeveroKavkazskogo Okruga No. F08-5405/11, 26 September 2011 (hereinafter the 'Decision of the Federal Arbitrazh Court of the North-Caucasian District No. F08-5405/11').

${ }^{107}$ Decision of the Federal Arbitrazh Court of the North-West District No. F07-8429/11 (n 100); Decision of the Arbitrazh Court of the Vologda District No. A13-1398/2011 (n 99).

${ }^{108}$ See Tsentr Infrastrukturnykh Issledovanii (n 9) 48 ff. On the importance for renewable energy investors of legal certainty regarding tariff levels, see Lucy Butler and Karsten Neuhoff, 'Comparison of Feed-in Tariff, Quota and Auction Mechanisms to Support Wind Power Development' (2008) 33 Renewable Energy 1854, 1864.

${ }^{109}$ Changes to the regulatory basis underlying renewable energy support schemes could be challenged under Article 1 of the first additional Protocol to the European Convention on Human Rights (right to property). See Anatole Boute, 'The Protection of Property Rights under the European Convention on Human Rights and the Promotion of Low-Carbon Investments' (2010) 1 Climate Law 93. However, in casu, the success of these cases is likely to be limited by the fact that the Government, in advance, announced the introduction of federal tariff methodologies, thereby affecting investors' legitimate expectations to benefit from regional RES-E tariffs.

${ }^{110}$ Item 38, Decree 1178.
} 
every year of the regulated period. On a yearly basis, the tariff authorities adapt the tariffs with the aim, among others, of reflecting the evolution of prices for the purchase of electricity in order to compensate network losses. ${ }^{111}$ These provisions seem to provide relatively solid guarantees to network companies that they will be able to recover the higher costs related to the compensation of losses with RES-E.

In practice, however, this recovery of costs will depend on whether the transmission tariffs remain within the limits of the FST determinations for the region. ${ }^{112}$ Indeed, an important constraint to regional RES-E tariff initiatives is that, according to the Government Decree No. 1178 on Electricity Retail Tariffs, ${ }^{113}$ retail tariffs and network tariffs must remain within federal tariff limits. Federal limits for network tariffs could jeopardise the recovery by the network companies of the higher costs for the compensation of network losses with RES-E.

\subsection{Tariff Duration}

Decree No. 1178 on Electricity Retail Tariffs provides that RES-E tariffs are determined on a yearly basis. ${ }^{114}$ This short-term duration of tariffs is incompatible with the long-term investment certainty needed to recover the capital costs of renewable energy projects. ${ }^{115}$ In the EU, support mechanisms generally apply for a period of at least ten years. Tariff unpredictability increases the returns that investors require to invest in new technologies: it requires investors to add a 'risk premium' to their business case, thereby reducing the amount of projects that might be financially viable. The risk premium issue is particularly acute in Russia, given the relatively risky business environment and regulatory instability.

\subsection{Enforceable Priority Purchase of Renewable Energy at Regulated Prices?}

Article 32 of the Federal Electricity Law requires network companies to compensate network losses using, as a priority, RES-E. Article 23.1 of this Law provides that regulated tariffs apply to the RES-E that network companies purchase to compensate their losses. However, the Federal Electricity Law does not explicitly make the link between the obligation to purchase as a priority RES-E and the regulated tariffs. ${ }^{116}$ The Law does not stipulate in the same article that network companies are obliged to compensate their losses as a priority with RES-E, which they must purchase at regulated prices. Moreover, the Law does not guarantee that renewable energy investors will be able to inject all the electricity they produce into the electricity network. In contrast to the common design of feed-in tariffs, the Law does not establish an obligation of priority access to the network. Although it makes logical sense to assume, on the basis of Articles 32 and 23.1 of the Federal Electricity Law, that network companies are obliged to purchase RES-E at regulated tariffs, the risk

\footnotetext{
${ }^{111}$ Item 37, Decree 1178.

${ }^{112}$ See IFC, Financing Renewable Energy Investments in Russia (n 91) 14. The increase of regional electricity prices is a sensitive issue at federal government level. In February 2013, the Minister of Energy and Utilities of the Murmansk Region was dismissed because of electricity price increases that were considered to be unacceptable by the federal authorities. See Prime, 'Murmansk Region Energy Minister Fired after Putin's Criticism', News Daily, 26 February 2013, 14.

${ }^{113}$ Item 62 and Item 79 of Decree 1178.

114 Item 63.

${ }^{115}$ See IFC, Financing Renewable Energy Investments in Russia (n 91) 12.

${ }^{116}$ See Tsentr Infrastrukturnykh Issledovanii (n 9) $48 \mathrm{ff}$.
} 
exists that companies could seek to rely upon a different interpretation of those Articles in order to escape this obligation. ${ }^{117}$

\section{Overcoming the Federal Barriers}

Federal barriers to regional (state-level) RES-E tariff policies are not unique to the Russian Federation. In the US, for instance, the initiative by the State of California to guarantee the purchase of RES-E at regulated prices for a long-term period was challenged on the basis of its alleged incompatibility with the Federal Power Act and the Public Utility Regulatory Policies Act. Interestingly, federal challenges to statelevel RES-E tariff initiatives in the US are very similar to the federal obstacles to regional RES-E tariffs in Russia: broad federal control over the electricity price determination process and federal qualification of renewable energy generating facilities. Given comparable federal barriers to regional RES-E tariff policies in the US and Russia, state-level regulatory solutions to circumvent these obstacles in the US can provide interesting input for the design of solutions to overcome federal barriers in Russia. Although the specific electricity market regulation in the US and Russia greatly varies, both federal states share comparable constitutional principles that make a comparative approach feasible.

\subsection{State-level RES-E Tariffs in the US: Lessons to Overcome Federal Barriers in Russia}

In the US, in accordance with the Federal Power Act, the Federal Energy Regulatory Commission (FERC) has exclusive jurisdiction to regulate the rates and conditions of electricity sales in interstate (wholesale) commerce, ${ }^{118}$ a notion that, according to its broad interpretation, ${ }^{119}$ includes virtually all power purchase agreements that a utility concludes with other producers. ${ }^{120}$ FERC approves the rates for all wholesale electricity sales by assessing, on a contract-by-contract basis, whether these rates are "just and reasonable" and do not unduly discriminate. ${ }^{121}$ For renewable energy generating facilities, the question is whether prices exceeding market prices, necessary to recover the relatively higher investment costs of these projects, are not inherently unjust and unreasonable. ${ }^{122}$ In a similar way to the principle of the 'economic well-founded nature of costs' in Russia, FERC adopts a cost-based approach in its assessment of electricity rates: rates are 'just and reasonable' if they allow recovery of prudent costs plus a reasonable return on investment. ${ }^{123}$ This approach does not necessarily exclude the higher costs of renewable energy investments, provided investors can demonstrate these costs were reasonably made.

\footnotetext{
${ }^{117}$ Ibid. The risk of claims against RES-E tariff obligation is far from being purely hypothetical. See the Vologda cases analysed above (nn 99-100).

118 16 U.S.C. para 824.

${ }^{119}$ Mississippi Power \& Light Co v Mississippi ex rel Moore 487 U.S. 354 (1988).

${ }^{120}$ Jim Rossi and Thomas Hutton, 'Federal Preemption and the Clean Energy Floor' North Carolina LR (forthcoming, 2013) 31 <http://papers.ssrn.com/sol3/papers.cfm?abstract_id=2146682\#\#> accessed 3 January 2013.

${ }^{121}$ The so-called 'filed-rate' doctrine. 16 USC PARA 824D. See Joshua Rokach, 'FERC's Jurisdiction under Section 205 of the Federal Power Act' (1994) 15 Energy LJ 83.

${ }^{122}$ Scott Hempling and others, Renewable Energy Pricing in State-level Feed-in Tariffs: Federal Law Limitations and Possible Solutions (National Regulatory Research Institute, 2010) 37 <http://www.nrel.gov/docs/fy10osti/47408.pdf> accessed 3 January 2013. 123 ibid.
} 
However, FERC's necessary review and approval of the costs on a contract-bycontract basis considerably limits the regulatory role of states in this process.

Under the Public Utility Regulatory Policies Act, states can require electricity utilities (suppliers) to purchase electricity produced by renewable energy installations at regulated prices. However, this right is also subject to stringent conditions and review by FERC. Only renewable energy installations that the FERC has approved as 'qualified facility' are eligible for regulated tariffs. ${ }^{124}$ More importantly, state-level electricity tariffs for these installations cannot exceed the 'avoided costs' of the purchasing utility, i.e. the costs that the utility would have incurred if it would have produced the electricity itself or purchased it from another source. ${ }^{125}$ FERC has strictly interpreted the notion of 'avoided costs': avoided cost rates must reflect the cost of electricity production from 'all sources able to sell' to the purchasing utility. ${ }^{126}$ Moreover, these rates must be based on 'real costs' that would 'actually be incurred by the utility'. ${ }^{127}$ Avoided cost rates may not compensate for environmental externalities ${ }^{128}$ that have not yet been internalised, but must be limited to pecuniary ('real') costs resulting from constraining environmental policies (e.g. emission reduction and renewable energy obligations). ${ }^{129}$

The Public Utility Regulatory Policies Act does not allow states to implement classical feed-in tariff schemes. Nevertheless, the Act, as interpreted by FERC, authorises states to adopt a creative approach to the definition of 'avoided costs' that could enable them to support the development of renewable energy. In the US, states, not the federal government, have the power to regulate the sources (fuel mix) for electricity production in their electricity systems. ${ }^{130}$ When determining the 'sources able to sell to the utility', states may take into account the obligations imposed on utilities to purchase a certain amount of electricity from renewable energy sources (e.g. by introducing so-called Renewable Portfolio Standard (RPS) requirements). According to FERC, 'where a state requires a utility to procure a certain percentage of energy from generators with certain characteristics [e.g. RES-E], generators with those characteristics [renewable energy generating facilities] constitute sources that are relevant to the determination of the utility's avoided cost for that procurement requirement. ${ }^{131}$ In the absence of a federal feed-in tariff scheme in the US, states could therefore guarantee the purchase of RES-E at regulated prices provided such price guarantees are directly linked with quantity-based obligations (RPS). ${ }^{132}$

\footnotetext{
${ }^{124} 18$ C.F.R. para 292.203(a), 292.203(c), 292.204 and 292.207.

125 C.F.R. para 292.101(b)(6).

${ }^{126}$ SoCal Edison, 70 FERC II 61,215 at 61,677

${ }^{127}$ SoCal Edison, 71 FERC II 61,269 at 62,080

${ }^{128}$ i.e. 'costs to society' in contrast to 'pecuniary costs'. Richard Cudahy, 'PURPA: The Integration of Competition and Regulatory Policy’ (1995) 16 Energy L J 419, 431-432.

${ }^{129}$ California Public Utilities Commission, 133 FERC II 61,059; SoCal Edison, 71 FERC II 61,269 at 62,080

${ }^{130}$ See 16 U.S.C. 824(b); Connecticut Department of Public Utility Control v FERC 569 F.3d 477, 481 (D.C. Cir. 2009) cert. denied, 130 S. Ct. 1051, 175 L. Ed. 2d 882 (2010). See also Amy Stein, 'An Enhanced Federal Role in Renewable Energy Siting' (Colloquium on Environmental Scholarship, Vermont Law School, September 2011).

${ }^{131}$ California Public Utilities Commission, 133 FERC 1 [ 61,059.

${ }^{132}$ See Michael Dorsi, 'Clean Energy Pricing and Federalism: Legal Obstacles and Options for Feed-in Tariffs' (2012) 32 Environs 175, 188.
} 
In the US, states are thus not free to design feed-in tariff schemes: FERC retains the exclusive right to assess and disapprove state-level tariffs. Past examples of rejection by FERC of state-level tariffs for alternative modes of electricity production ${ }^{133}$ highlights that the risk of federal 'intrusion" ${ }^{134}$ with regional clean energy policies is not merely hypothetical. However, by linking price-based guarantees (feed-in) to quantity-based (RPS) obligations, states can minimise the risk of federal invalidation of their renewable energy tariff policies. Could this scheme be replicated in Russia to overcome the federal obstacles that regions face regarding their RES-E tariff policies?

\subsection{Linking Price- and Quantity-based Schemes in the Regions of the Russian Federation}

As described above, in Russia, regional support for renewable energy is anchored in the retail market (i.e. for installations under $25 \mathrm{MW}$ ) and based on the priority purchase of RES-E by the network companies to compensate losses on their network. In accordance with the Federal Electricity Law, regional authorities can adopt specific tariffs for the electricity that network companies purchase from renewable energy generating facilities. However, federal control over these tariffs and over the qualification of RES installations, together with regulatory uncertainty concerning the obligation of network companies to purchase RES-E at regulated tariffs, reduces the effectiveness of this scheme. In the absence of regulatory amendments to address these obstacles, the question is if, following the US case, regions could impose quantity-based RES obligations on network companies and link these obligations to long-term price guarantees for RES investors. The necessary legislative basis for this approach should not be sought in the Federal Electricity Law, but in Russian energy efficiency law.

The Federal Energy Efficiency Law mandates regional authorities to encourage network companies to improve the energy efficiency of their activities and reduce losses on their network. ${ }^{135}$ They can require companies that provide regulated services to implement certain energy saving measures. ${ }^{136}$ The investment programs of regulated companies (such as network companies) must include the energy efficiency requirements that the competent authorities determine for those companies. ${ }^{137}$ As described above, the Federal Energy Efficiency Law includes renewable energy under the concept of energy efficiency. Electricity production from renewable energy sources can be considered as an energy saving measure within the meaning of the Federal Energy Efficiency Law. On this basis, regional authorities could establish the compensation of network losses with RES-E as a requirement of the energy efficiency program of the network company and include these requirements in the investment programs of the network companies. ${ }^{138}$ The PPAs that the network companies would

\footnotetext{
${ }^{133}$ See Southern Cal. Edison Co., 71 FERC II 61,269; 70 FERC II 61,215; Connecticut Light \& Power Co., 70 FERC $9161,012$.

${ }^{134}$ David Yaffe, 'Are State Renewable Feed-in Tariff Initiatives Truly Throttled by Federal Status After the California Decision' (2010) 23 The Electricity J 9.

${ }^{135}$ Art 14, para 6 FZ-261

${ }^{136}$ Art 25, para 2 FZ-261

${ }^{137}$ Art 25, para 5 FZ-261

${ }^{138}$ According to the criteria established in Decree No. 977 on Investment Programs in the Electricity Sector, the Ministry of Energy - and not the regional authorities - is in charge of the approval of the investment program of the large regional network companies. However, regional authorities exercise influence over these investment programs: investment programs need to include the energy efficiency
} 
sign with renewable energy investors would be then considered as an energy saving measure.

Including the PPA with RES-E investors as an energy saving measure in the investment program of the network company has important consequences from a tariff perspective. Firstly, by introducing the obligation to compensate network losses with RES-E in the energy efficiency programs - and thus indirectly the investment programs - of network companies, regional authorities could circumvent the tariff limits set by the FST. Indeed, in accordance with paragraph 7 of Article 23.1 of the Federal Electricity Law, regional tariff authorities can exceed federal tariff limits if this is necessary to implement the investment programs of the companies concerned. Secondly, in accordance with paragraph 7 of Article 25 of the Federal Energy Efficiency Law, the tariffs of companies that provide regulated services should reflect the costs incurred to implement investment programs. By requiring the network company to compensate network losses with RES-E, the regional authorities would thus facilitate the recovery of the costs related to the purchase of RES-E (i.e. the costs of the PPA with renewable energy investors). In addition, to facilitate the recovery of the costs of the PPA, and thus indirectly the (capital) costs of the RES investment concerned, regional authorities could make use of the long term tariff guarantees of paragraph 6 of Article 25 of the Federal Energy Efficiency Law. According to this provision, to stimulate energy savings, tariffs must be determined on a long-term basis. The regional tariff authorities could therefore guarantee long-term parameters of tariff regulation in agreements with the network company.

Importantly, by including the obligation to compensate network losses with RES-E in the energy efficiency and investment programs of network companies, regions can circumvent the federal qualification barrier. Indeed, the Federal Energy Efficiency Law does not make the inclusion of renewable energy measures in energy efficiency programs subject to any qualification requirement. Regions must respect the definition of renewable energy in the Federal Electricity Law. They are, however, free to adopt their own qualification procedure with respect to the implementation of regional energy efficiency policies.

From an energy savings perspective, it must be noted that the compensation of network losses with RES-E must be considered in parallel with improvements of the network infrastructure to limit losses. It does not make sense to compensate losses with increased electricity production - even from renewable energy sources - if these losses could be avoided by energy efficiency improvements of the networks.

\section{Conclusion}

Despite its huge renewable energy potential, Russia lags far behind most other developed and emerging economies in the clean energy sector. The political sensitivity of price increases - necessary in the short term to ensure the financial viability of renewable energy investments - has so far blocked the implementation of

programs developed by regional authorities. Moreover, regional authorities have the right to comment on the investment programs proposed by network companies (see Postanovlenie Pravitel'stva RF Ob Investitsionnykh Programmakh Sub' 'ektov Elektroenergetiki, No. 977, signed 1 December 2009, Sobranie Zakonodatel'stva Rossiiskoi Federatsii (SZ RF) (7 December 2009) No. 49 item 5978 (hereinafter the 'Government Decree on the Investment Programmes of Electricity Companies'). 
a federal support scheme. In this context, based on the environmental federalism literature, there are good reasons to believe that regional authorities can be more effective actors for the development of renewable energy sources in Russia. Indeed, regions have a more direct interest in the local economic and environmental benefits that renewable energy represents. Depending on their resource base and the costs associated with its development, regions could therefore more easily justify the necessary price increases.

However, given the centralisation of power in Russia, particularly in the electricity sector and in respect of tariff regulation, regional renewable energy policy initiatives face not insignificant federal barriers. Federal control over tariffs and federal qualification of renewable energy installations present the risk of constraining regional RES-E tariff initiatives. In the absence of federal support, it is essential, from a sustainable energy perspective, that regions overcome these barriers in order to act as innovators in this field and to contribute to the modernisation of the Russian energy infrastructure.

Broader regional powers under the Federal Energy Efficiency Law, together with the inclusion of renewable energy as part of the concept of energy efficiency, provide regions with the necessary legal basis to pursue an ambitious renewable energy program. Regions can, on this basis, impose on network companies the obligation to compensate their losses with RES-E and ensure recovery of the costs associated with this obligation through energy efficiency tariff guarantees. This combined quantityand price-based approach to the support of renewable energy is inspired by the debate on state-level feed-in tariffs in the US. It could provide the regions of the Russian Federation with the necessary scope to act as 'regulatory safety nets', to start the development of renewable energy in Russia and possibly influence the implementation of a functioning federal scheme. 